\title{
The aryl hydrocarbon receptor ligand omeprazole inhibits breast cancer cell invasion and metastasis
}

\author{
Un-Ho Jin ${ }^{1 \dagger}$, Syng-Ook Lee ${ }^{1 \dagger}$, Catherine Pfent ${ }^{2}$ and Stephen Safe ${ }^{1,3^{*}}$
}

\begin{abstract}
Background: Patients with ER-negative breast tumors are among the most difficult to treat and exhibit low survival rates due, in part, to metastasis from the breast to various distal sites. Aryl hydrocarbon receptor (AHR) ligands show promise as antimetastatic drugs for estrogen receptor (ER)-negative breast cancer.

Methods: Triple negative MDA-MB-231 breast cancer cells were treated with eight AHR-active pharmaceuticals including 4-hydroxtamoxifen, flutamide leflunomide, mexiletine, nimodipine, omeprazole, sulindac and tranilast, and the effects of these compounds on cell proliferation (MTT assay) and cell migration (Boyden chamber assay) were examined. The role of the AHR in mediating inhibition of MDA-MB-231 cell invasion was investigated by RNA interference (RNAi) and knockdown of AHR or cotreatment with AHR agonists. Lung metastasis of MDA-MB-231 cells was evaluated in mice administered cells by tail vein injection and prometastatic gene expression was examined by immunohistochemistry.

Results: We showed that only the proton pump inhibitor omeprazole decreased MDA-MB-231 breast cancer cell invasion in vitro. Omeprazole also significantly decreased MDA-MB-231 cancer cell metastasis to the lung in a mouse model (tail vein injection), and in vitro studies showed that omeprazole decreased expression of at least two prometastatic genes, namely matrix metalloproteinase-9 (MMP-9) and C-X-C chemokine receptor 4 (CXCR4). Results of RNA interference studies confirmed that omeprazole-mediated downregulation of CXCR4 (but not MMP-9) was AHR-dependent. Chromatin immunoprecipitation assays demonstrated that omeprazole recruited the AHR to regions in the CXCR4 promoter that contain dioxin response elements (DREs) and this was accompanied by the loss of pol II on the promoter and decreased expression of CXCR4.
\end{abstract}

Conclusions: AHR-active pharmaceuticals such as omeprazole that decrease breast cancer cell invasion and metastasis may have important clinical applications for late stage breast cancer chemotherapy.

Keywords: Omeprazole, Ah receptor, Metastasis, Inhibition, CXCR4

\section{Background}

The aryl hydrocarbon receptor (AHR) is a ligand-activated transcription factor that was first discovered as an intracellular protein that bound with high affinity to the environmental toxicant 2,3,7,8-tetrachlorodibenzo- $p$-dioxin (TCDD) [1]. Subsequent studies showed that AHR-mediated transcription was dependent on formation of a nuclear heterodimer composed of the AHR and AHR nuclear translocator (ARNT) proteins [2] that bind AHR responsive elements

\footnotetext{
* Correspondence: ssafe@cvm.tamu.edu

${ }^{\dagger}$ Equal contributors

'Institute of Biosciences and Technology, Texas A\&M Health Sciences Center, 2121 W. Holcombe Blvd., Houston, TX 77030, USA

${ }^{3}$ Department of Veterinary Physiology and Pharmacology, Texas A\&M

University, 4466 TAMU, College Station, TX 77843, USA
}

Full list of author information is available at the end of the article
(AhREs) on target gene promoters [3]. Initial studies demonstrated that TCDD and structurally-related halogenated aromatic compounds induced a well-defined subset of genes and toxic responses [4]. However, it is now apparent that this receptor plays a critical endogenous role in cellular homeostasis and multiple diseases and binds not only toxicants but also endogenous biochemicals, dietary flavonoids and several phytochemicals associated with health benefits, other synthetic/industrial chemicals, and many pharmaceuticals [5-7]. The important role of the AHR and effects of AHR agonists or antagonists have been documented for various inflammatory conditions, stem cell stability and expansion, autoimmune diseases, and several different cancers and clearly demonstrate that this receptor is an important drug target [8-15].

\section{Ciomed Central}

(c) 2014 Jin et al.; licensee BioMed Central Ltd. This is an Open Access article distributed under the terms of the Creative Commons Attribution License (http://creativecommons.org/licenses/by/2.0), which permits unrestricted use, distribution, and reproduction in any medium, provided the original work is properly credited. 
Research in this laboratory initially focused on the molecular mechanisms of inhibitory AHR-estrogen receptor (ER) crosstalk and development of selective AHR modulators (SAhRMs) for treatment of ER-positive breast cancer [16,17]. 6-Methyl-1,3,8-trichlordibenzofuran (6-MCDF) was initially developed as a relatively non-toxic AHR antagonist that inhibited TCDD-induced toxicity in rodent models [18-22]. However, this compound also exhibited AHR agonist activity and activated inhibitory AHR-ER $\alpha$ crosstalk in breast cancer cells and decreased mammary tumor growth in vivo $[17,23,24]$. Subsequent studies showed that MCDF also blocked growth of ER-negative breast cancer cells [25] and inhibited metastasis of triple negative MDA-MB-231 breast cancer cells to the lung by inducing the antimetastatic microRNA-335 (miR-335) [26]. Recent studies showed that eight AHR-active pharmaceuticals including 4-hydroxtamoxifen, flutamide leflunomide, mexiletine, nimodipine, omeprazole, sulindac and tranilast exhibited structure- and cell context-dependent AHR agonist/antagonist activities in BT474 and MDA-MB-468 cells and several of these compounds also inhibited MDAMB-468 cell migration [27]. These results are typically observed for selective AhR modulators (SAhRMs) that exhibit tissue- and response-specific AhR agonist or antagonist activity due to differential expression of cofactors, different receptor/ligand conformations and epigenetic effects [16]. Selective receptor modulators are also commonly observed for nuclear receptors such as the estrogen receptor (ER) and selective ER modulators have been extensively characterized for treatment of ER-positive breast cancer [28].

In this study, we initially used the same set of AHRactive pharmaceuticals in triple-negative MDA-MB-231 cells with a primary objective of identifying a known pharmaceutical that may be effective for inhibiting breast cancer metastasis. Among the eight compounds, only omeprazole inhibited MDA-MB-231 breast cancer cell invasion and this response could be reversed, in part, by AHR antagonists or by knockdown of the AHR by RNA interference (RNAi). Omeprazole also inhibited lung metastasis of MDA-MB-231 cells (tail vein injection) in a mouse model and the antimetastatic pathway was linked to decreased expression of MMP-9 and AHR-dependent suppression of the pro-metastatic gene CXCR4. Decreased invasion and CXCR4 expression was also observed in MCF-7 and SKBR3 breast cancer cell lines treated with omeprazole. Thus, omeprazole may have potential clinical applications for inhibition of breast cancer metastasis due, in part, to its AHR agonist activity.

\section{Methods}

Cell lines, antibodies, and reagents and MTT assay

MDA-MB-231, MCF-7, SKBR3 and MDA-MB-468 human breast cancer cell lines were obtained from the
American Type Culture Collection (Manassas, VA). Cells were maintained in Dulbecco's modified Eagle's medium (DMEM) nutrient mixture supplemented with $0.22 \%$ sodium bicarbonate, $0.011 \%$ sodium pyruvate, $10 \%$ fetal

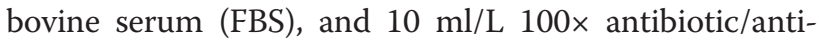
mycotic solution (Sigma-Aldrich, St. Louis, MO). Cells were maintained at $37^{\circ} \mathrm{C}$ in the presence of $5 \% \mathrm{CO}_{2}$, and the solvent (dimethyl sulfoxide, DMSO) used in the experiments was $\leq 0.2 \%$. CYP1A 1 , AHR, PCNA, and $\beta$-actin antibodies were purchased from Santa Cruz Biotechnology (Santa Cruz, CA), and CXCR4 and RNA polymerase II antibody were purchased from GeneTex (Irvine, CA). All compounds used in this study and reagents for cell staining and MTT assay were purchased from Sigma-Aldrich. Cells $\left(5 \times 10^{3}\right.$ per well $)$ were plated in 96-well plates and allowed to attach for $16 \mathrm{hr}$, and the effects of various AHR-active compounds on cell proliferation were determined in an MTT assay as previously described [27].

\section{Chromatin immunoprecipitation (ChIP) assay}

The ChIP assay was performed using ChIP-IT Express Magnetic Chromatin Immunoprecipitation kit (Active Motif, Carlsbad, CA) according to the manufacturer's protocol. MDA-MB-231 cells $\left(5 \times 10^{6}\right.$ cells $)$ were treated with TCDD or omeprazole for $2 \mathrm{hr}$, and the ChIP assay was carried out as previously described [27]. The CXCR4123 primers were $5^{\prime}$ - ATC CCT GGC ATT TCA TCT CTC C-3' (sense) and 5'- ACA ACA CCG TGT GGG TAT TAC C-3' (antisense) and the CXCR4-4 primers were 5' - ACT CAC TAC CGA CCA CCC GC-3' (sense) and 5' - CGT CAC TTT GCT ACC TGC TGC C-3' (antisense), and then respectively amplified a 171-bp and 232bp region of human CXCR4 promoter which contained the AHR binding sequences. The cytochrome P4501A1 (CYP1A1) primers were 5' -TCA GGG CTG GGG TCG CAG CGC TTC T-3' (sense), and 5'-GCT ACA GCC TAC CAG GAC TCG GCA G-3' (antisense), and then amplified a 122-bp region of human CYP1A1 promoter which contained the AHR binding sequences [27]. PCR products were resolved on a $2 \%$ agarose gel in the presence of ETBR.

\section{Quantitative real-time PCR}

cDNA was prepared from the total RNA of cells using High Capacity RNA-to-cDNA Kit (Applied Biosystems, Foster City, CA) as previously described [27]. Values for each gene were normalized to expression levels of TATA-binding protein. The sequences of the primers used for real-time PCR were as follows: CYP1A1 sense 5' - GAC CAC AAC CAC CAA GAA C-3', antisense 5' AGC GAA GAA TAG GGA TGA AG-3'; cytochrome P4501B1 (CYP1B1) sense 5' - ACC TGA TCC AAT TCT GCC TG-3', antisense 5' - TAT CAC TGA CAT 
CTT CGG CG-3'; CXCR4 sense 5'- TTT TCT TCA CGG AAA CAG GG-3', antisense 5' - GTT ACC ATG GAG GGG ATC AG-3'; MMP-9 sense 5' - TTG GTC CAC CTG GTT CAA CT-3', antisense 5' - ACG ACG TCT TCC AGT ACC GA-3'; and TBP sense 5'-TGC ACA GGA GCC AAG AGT GAA-3', antisense 5' -CAC ATC ACA GCT CCC CAC CA-3'.

\section{Western blot analysis}

Cells $\left(3 \times 10^{5}\right)$ were plated in 6-well plates in DMEM media containing $2.5 \%$ FBS for $16 \mathrm{hr}$ and then treated with different concentrations of the compounds, and whole cell lysates were analyzed by western blots essentially as described [27].

\section{Scratch and invasion assay}

After cells were more than $80 \%$ confluent in 6-well plates, the scratch was made using a sterile pipette and then treated with vehicle (DMSO) or compounds. Cell migration into the scratch was determined after $18 \mathrm{hr}$ (7-8 determinations/treatment). For invasion assay of MDA-MB-231 cells, the BD-Matrigel Invasion Chamber (24-transwell with $8 \mu \mathrm{m}$ pore size polycarbonate membrane) was used in a process of modified Boyden chamber assay essentially as described [27].

\section{Transfection of siRNAs and luciferase assays}

Cells $\left(2 \times 10^{5}\right.$ cells/well) were plated in 6 -well plates in DMEM media supplemented with 10\% FBS. After $16 \mathrm{hr}$, the cells were transfected with $100 \mathrm{nM}$ of each siRNA duplex for $6 \mathrm{hr}$ using Lipofectamine 2000 reagent (Invitrogen) following the manufacturer's protocol essentially as described [27]. In the AhR knockdown experiments, cells were transfected with AhR siRNA or a non-specific (control) oligonucleotide [25-27]. The CXCR4 (NM_003467) promoter clone (CXCR4 promoter-Gaussia luciferase reporter construct containing secreted alkaline phosphatase) and Secrete-Pair Gaussia Luciferase Assay Kit were purchased from Genecopoeia (Rockville, MD). Cells $\left(4 \times 10^{4}\right.$ cells/well) were plated in 12-well plates in DMEM media supplemented with 10\% FBS and transfection experiments were carried out as described [27]. A multifunctional microplate reader (FLUOstar OPTIMA) was used to quantitate luciferase and phosphatase activities, and the luciferase activities were normalized to alkaline phosphatase activity.

\section{Tail vein injection for metastasis in athymic mice and} immunohistochemistry

Female athymic nude mice (Foxn $1^{n u}$, ages 6-8 weeks) were purchased from Harlan Laboratories. Animal work was approved by the Institutional Animal Care and Use Committee (IACUC) at Texas A\&M University. MDAMB-231 cells $\left(1 \times 10^{6}\right.$ cells $)$ in PBS were injected through the tail vein of nude mice to create pulmonary metastasis, and mice were randomly divided into 2 groups of 6 animals each. Either corn oil (control) or omeprazole $(100 \mathrm{mg} / \mathrm{kg} /$ day) in corn oil was orally administered to each group for 4 weeks, respectively. The lung tissues were fixed in 10\% neutral buffered formalin and further examined by routine (H\&E) and immonohistochemical staining. Paraffin-embedded lung tissue sections (5- $\mu \mathrm{m}$ thick) were analyzed for CXCR4 and proliferating cell nuclear antigen (PCNA) as previously described [27].

\section{Statistics}

All of the experiments were repeated a minimum of three times. The data are expressed as the means $\pm \mathrm{SE}$. Statistical significance was analyzed using either Student's t-test or analysis of variance (ANOVA) with Scheffe's test. The results are expressed as means with error bars representing 95\% confidence intervals for three experiments for each group unless otherwise indicated, and a $P$ value of less than 0.05 was considered statistically significant.

\section{Results}

Omeprazole inhibits MDA-MB-231 cell invasion

Table 1 and Additional file 1: Figure S1, Additional file 2: Figure S2 and Additional file 3: Figure S3 show that the eight AHR-active pharmaceuticals differentially activated CYP1A1 and CYP1B1 mRNA levels in MDA-MB-231 cells, and only 4-hydroxytamoxifen induced $>50 \%$ of the maximal response for both genes compared to $10 \mathrm{nM}$ TCDD (100\% response). Induction of CYP1A1 and CYP1B1 are prototypical markers of AH-responsiveness of cells to TCDD and other AHR agonists. Induction of CYP1A1 protein by these compounds was variable and 4-hydroxytamoxifen did not induce this response. TCDD typically induces proteasome-dependent degradation of the AhR and this was observed in MDA-MB-231 cells (Additional file 3: Figure S3). The effects of the AhR pharmaceuticals on AhR levels were highly variable, and

Table 1 AHR-active pharmaceuticals as AHR agonists in MDA-MB-231 breast cancer cells

\begin{tabular}{lcccccc}
\hline AHR agonist & \multicolumn{2}{c}{ mRNA } & & \multicolumn{2}{c}{ Protein } \\
\cline { 2 - 3 } CYP1A1 & CYP1B1 & & CYP1A1 & AHR \\
Sulindac & $>50$ & $>50$ & & ni & decreased \\
Flutamide & $<50$ & $>50$ & & ni & decreased \\
Tranilast & $<50$ & $>50$ & & ni & & unchanged \\
Leflunomide & $<50$ & $<50$ & & ind & & decreased \\
Nimodipine & $<50$ & $>50$ & & ind & & decreased \\
Mexiletine & $<50$ & $>50$ & & ind & & decreased \\
Omeprazole & $<50$ & $>50$ & & ind & decreased \\
\hline
\end{tabular}

$>50+<50$ are the $\%$ of TCDD-induced, response (100\%).

$\mathrm{ni}=$ no induction; $\mathrm{md}=$ induction 
notable decreases were observed for leflunomide, nimodipine, sulindac and 4-hydroxytamoxifen and this did not correlate with their effects on other measures of Ahresponsiveness. The variable response patterns observed for these compounds in MDA-MB-231 cells paralleled their structure- and cell context-dependent variability as AHR agonists and antagonists as previously observed in MDA-MB-468 and BT474 cells [27]. However, treatment of MDA-MB-231 cells with the AHR-active pharmaceuticals using concentrations of each compound that were not cytotoxic ( $\leq 20 \%$ growth inhibitory effect) (Additional file 4: Figure S4) showed that among these compounds, only
200 and $300 \mu \mathrm{M}$ omeprazole inhibited MDA-MB-231 cell migration in a Boyden chamber assay (Figure 1).

Inhibition of breast cancer cell invasion and metastasis: role of the AHR

The role of the AHR in mediating inhibition of MDA-MB231 cell invasion was investigated by RNA interference (RNAi) and cotreatment with AHR agonists. Figure 2A shows that TCDD- and omeprazole-mediated inhibition of invasion was significantly reversed in cells transfected with a small inhibitory RNA against the AHR (siAHR) compared to a control oligonucleotide (siCT). Knockdown of a

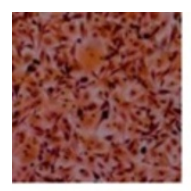

DMSO

b

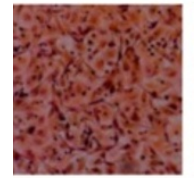

$50 \mu \mathrm{M}$

Leflunomide

C

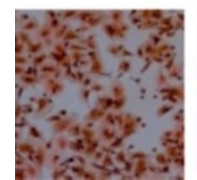

$200 \mu \mathrm{M}$

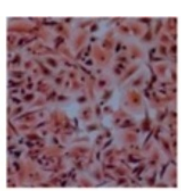

$10 \mathrm{nM}$ TCDD

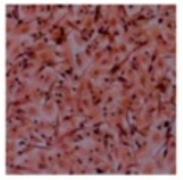

$100 \mu \mathrm{M}$

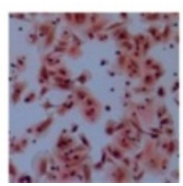

Omeprazole

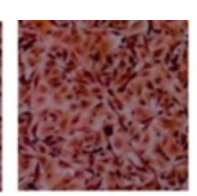

$4 \mu \mathrm{M}$

4OH-

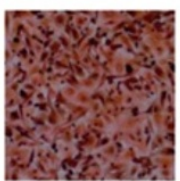

$400 \mu \mathrm{M}$

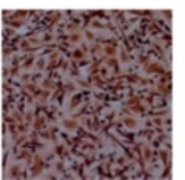

$100 \mu \mathrm{M}$

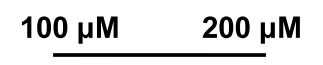

Sulindac

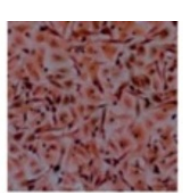

$25 \mu \mathrm{M}$

Flutamide

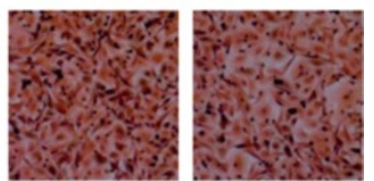

$20 \mu \mathrm{M}$

$40 \mu \mathrm{M}$

d

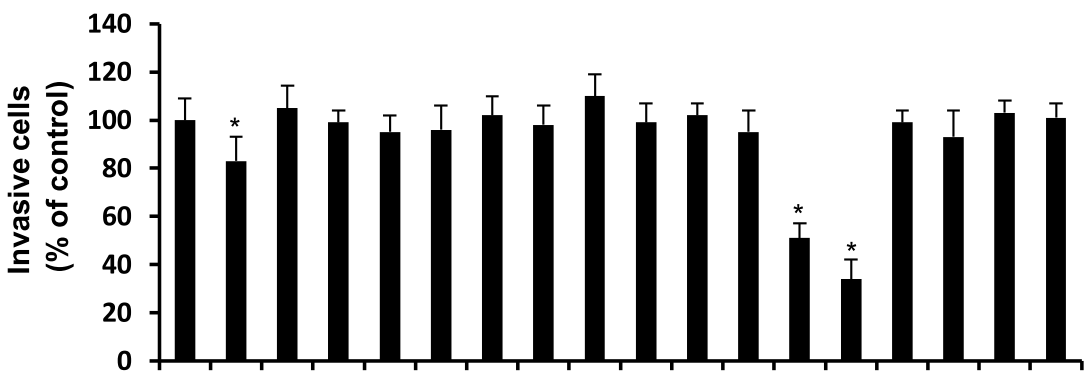

Agonist $(\mu \mathrm{M})$

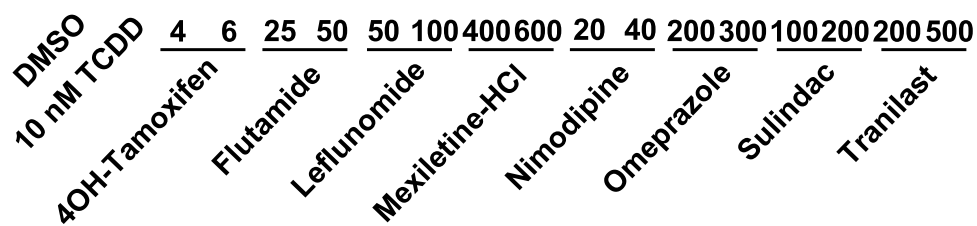

Figure 1 Omeprazole inhibits MDA-MB-231 cell invasion. (a)-(c) MDA-MB-231 cells were treated with omeprazole, other AHR-active pharmaceuticals and TCDD, and MDA-MB-231 cancer cell invasion was determined using a Boyden chamber assay as outlined in the Methods. (d) Quantitation of drug-induced inhibition of invasion. Experiments outlined in (a)-(c) were determined in triplicate and results are expressed as means \pm SE. Significant $(p<0.05)$ inhibition of invasion is indicated. 


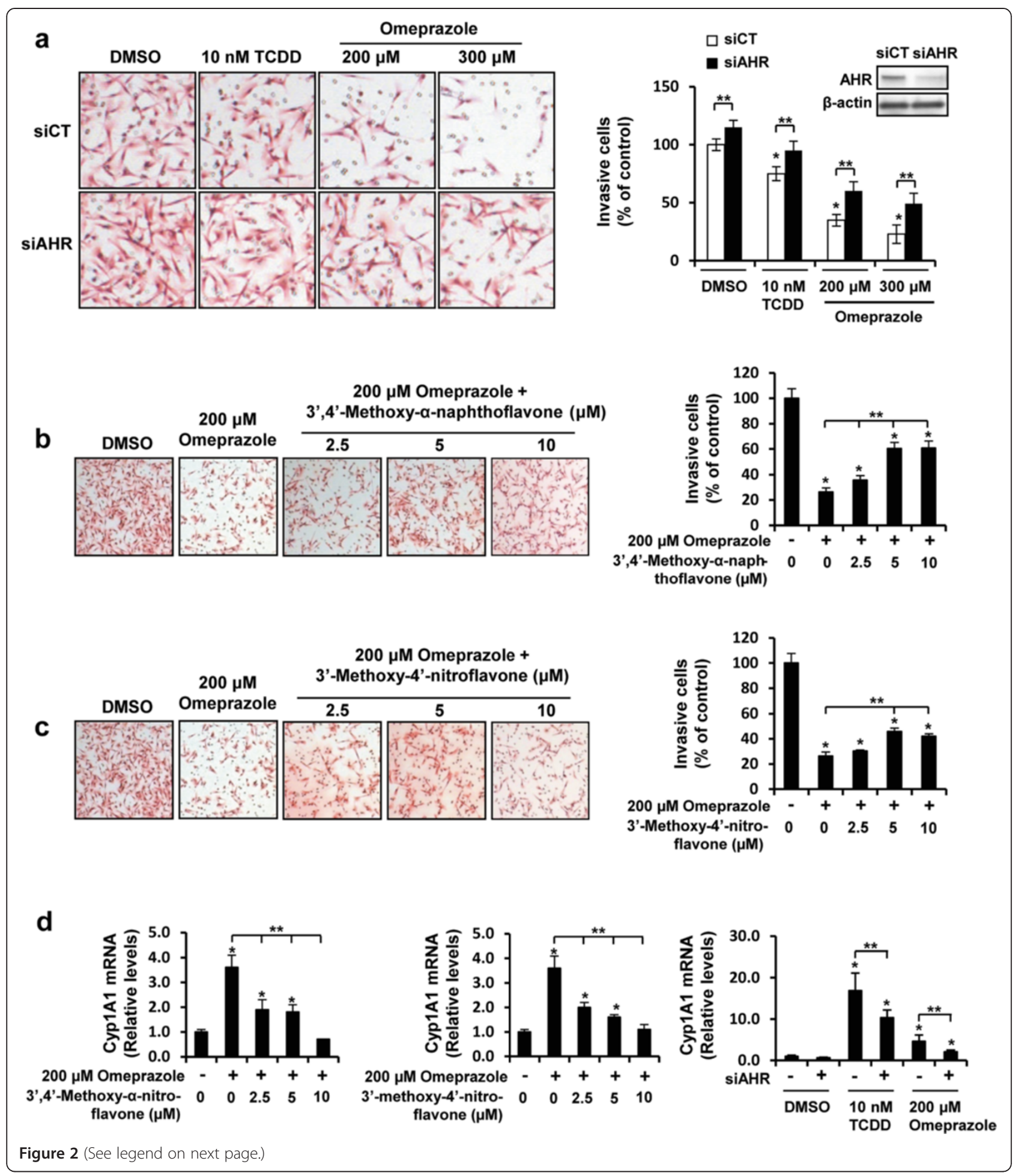


(See figure on previous page.)

Figure 2 Role of the AHR in mediating inhibition of MDA-MB-231 cell invasion by omeprazole. (a) AHR silencing. MDA-MB-231 cells were transfected with siCtl (control) and siAHR (targeting AHR) oligonucleotides treated with DMSO, TCDD or omeprazole, and effects on cell invasion were determined in a Boyden Chamber assay as outlined in the Methods. Significant $(p<0.05)$ inhibition of invasion $(*)$ and reversal of these effects by siAHR $\left(^{* *}\right)$ are indicated. Similar results were observed with another siAHR oligonucleotide (data not shown). AHR antagonists 3',4'-dimethoxy-a-naphthoflavone (b) and 3'-methoxy-4'-nitroflavone (c) block omeprazole-induced effects on invasion. Cells were treated with DMSO, omeprazole and the AHR antagonists alone or in combination, and cell invasion was determined in a Boyden chamber assay as outlined in the Methods. Significant $(p<0.05)$ inhibition of invasion $\left(^{*}\right)$ and rescue by the AHR antagonists $(* *)$ is indicated. (d) AHR antagonist and silencing inhibits induction of CYP1A1 mRNA by omeprazole. Cells were treated with DMSO, omeprazole and the antagonists alone or in combination (right and middle panel) or transfected with siCtl or siAHR and treated with DMSO, TCDD or omeprazole, and CYP1A1 mRNA levels were determined by real time PCR as outlined in the Methods. Significant $(p<0.05)$ induction of CYP1A1 $\left({ }^{*}\right)$ and reversal of this effect $\left(^{* *}\right)$ are indicated. Results $(\mathrm{a}-\mathrm{d})$ are expressed as means \pm SE for at least 3 replicate experiments for each treatment group.

the AHR alone also significantly increased MDA-MB-231 cell invasion, suggesting that the receptor alone inhibited invasion. Similar results were observed in MDA-MB-231 cells cotreated with omeprazole and the AHR antagonists $3{ }^{\prime}, 4{ }^{\prime}$-methoxy- $\alpha$-naphthoflavone (Figure 2B) [29] and 3'methoxy-4' -nitroflavone (Figure 2C) [30], further confirming a role for the AHR in mediating the inhibitory effects of omeprazole on MDA-MB-231 breast cancer cell invasion. As a positive control, we also showed that AHR knockdown and the AHR antagonists also inhibited induction of CYP1A1 by TCDD and omeprazole (Figure 2D).

TCDD (10 nM) and omeprazole (200 and $300 \mu \mathrm{M})$ significantly decreased MDA-MB-231 cell migration in a scratch assay (Figure 3A) and these results paralleled the inhibition MDA-MB-231 cell invasion after treatment with omeprazole. We also screened for expression of several genes associated with cancer cell invasion and metastasis and observed that omeprazole and TCDD decreased expression of MMP-9 and CXCR4 (Figures 3B), and the latter pro-metastatic gene has previous been shown to be repressed by TCDD and other AHR ligands in breast cancer cells [31-34]. The antimetastatic activity of omeprazole was also investigated in athymic nude mice injected (tail vein) with MDA-MB-231 cells and treated with $100 \mathrm{mg} / \mathrm{kg} / \mathrm{d}$ omeprazole for 28 days. Treatment-related weight loss was not observed, and $H \& E$ staining was used to evaluate and quantify the total number of tumor cells relative to the number of pneumocytes. In vehicle control mice, 9,785 tumor cells were counted in fifty frames with 46,653 pneumocytes (21.0\%), whereas in omeprazole-treated mice, 3,552 tumor cells were counted with 43,086 pneumocytes (8.2\%). These results demonstrate that omeprazole significantly inhibited lung metastasis of MDA-MB-231 cells by tail vein injection and this is illustrated in Figure 3C. Lung tumors were also immunostained for CXCR4 and PCNA (Figure 3D) and the decreased expression of both markers in the metastasized tumors in omeprazole-treated mice, suggesting that omeprazole also directly affected these tumors after metastasis to the lung.

Omeprazole also induced CYP1A1 and decreased CXCR4 mRNA levels in MCF-7 and MDA-MB-468 cells
(Figure 4A). Knockdown of the AHR in these cell lines decreased AHR mRNA levels and significantly reversed omeprazole-mediated induction of CYP1A1 (Figure 4B) and inhibition of CXCR4 (Figure 4C) mRNA levels in both cell lines. Omeprazole inhibits MDA-MB-468 cell migration [27]; however, this cell line did not exhibit invasion. PMA induced invasion of MCF-7 cells and this response was inhibited by omeprazole and partially reversed in cells transfected with siAHR (Figure 4C). Thus, the effects of omeprazole in the two AH-responsive MCF-7 and MDA-MB-468 cell lines were similar to that observed in MDA-MB-231 cells.

\section{Repression of CXCR4 expression by omeprazole is AHR-dependent}

Results in Figure 5A show that omeprazole and TCDD decreased expression of CXCR4 mRNA levels in MDAMB-231 cells and this was partially reversed in cells transfected with siAHR, and similar results were observed for CXCR4 protein. Omeprazole and TCDD decreased MMP-9 activity (by zymography and mRNA); however, AHR silencing did not attenuate downregulation of MMP-9 mRNA levels (Figure 5B, right panel), suggesting that downregulation of MMP-9 was AHRindependent. TCDD and omeprazole decreased luciferase activity in MDA-MB-231 cells transfected with the CXCR4-luc construct which contains the -1121 to +95 region of the CXCR4 promoter (Figure 5C). TCDD- and omeprazole-induced downregulation of luciferase activity was significantly reversed in cells cotransfected with siAHR or cotreated with the AHR antagonist 3'4'dimethoxy- $\alpha$-naphthoflavone (Figure $5 \mathrm{C}$ ), confirming a role for the AHR in mediating this response. The role of CXCR4 downregulation in mediating the inhibitory effects of omeprazole on MDA-MB-231 cell invasion was supported by results showing that knockdown of CXCR4 by RNAi also decreased invasion of MDA-MB-231 cells (Figure 5D).

The proximal Ah-responsive region of the CXCR4 promoter contains 4 putative DREs with a core GCGTG AHR complex binding motif (Figure 6A), and primers for the upstream DRE-123 and downstream DRE-4 
a

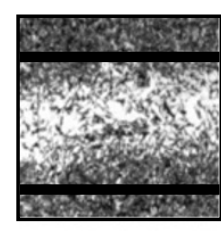

DMSO

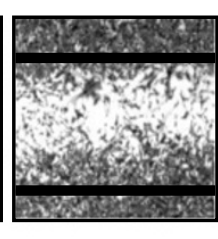

$10 \mathrm{nM}$ TCDD

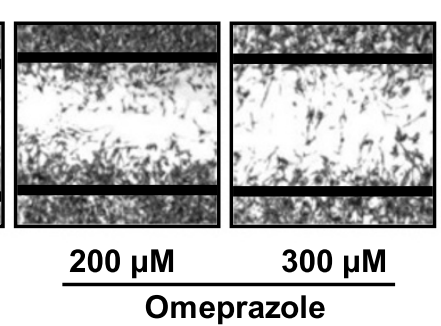

b
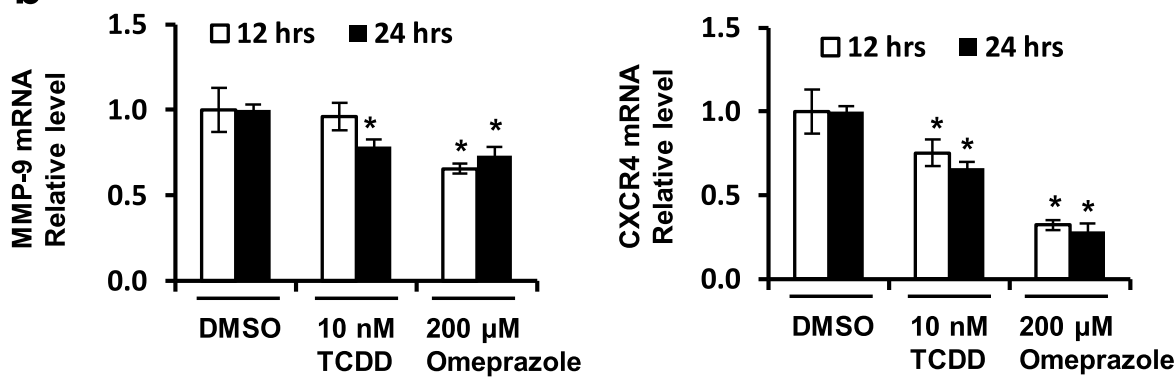

C

Corn oil
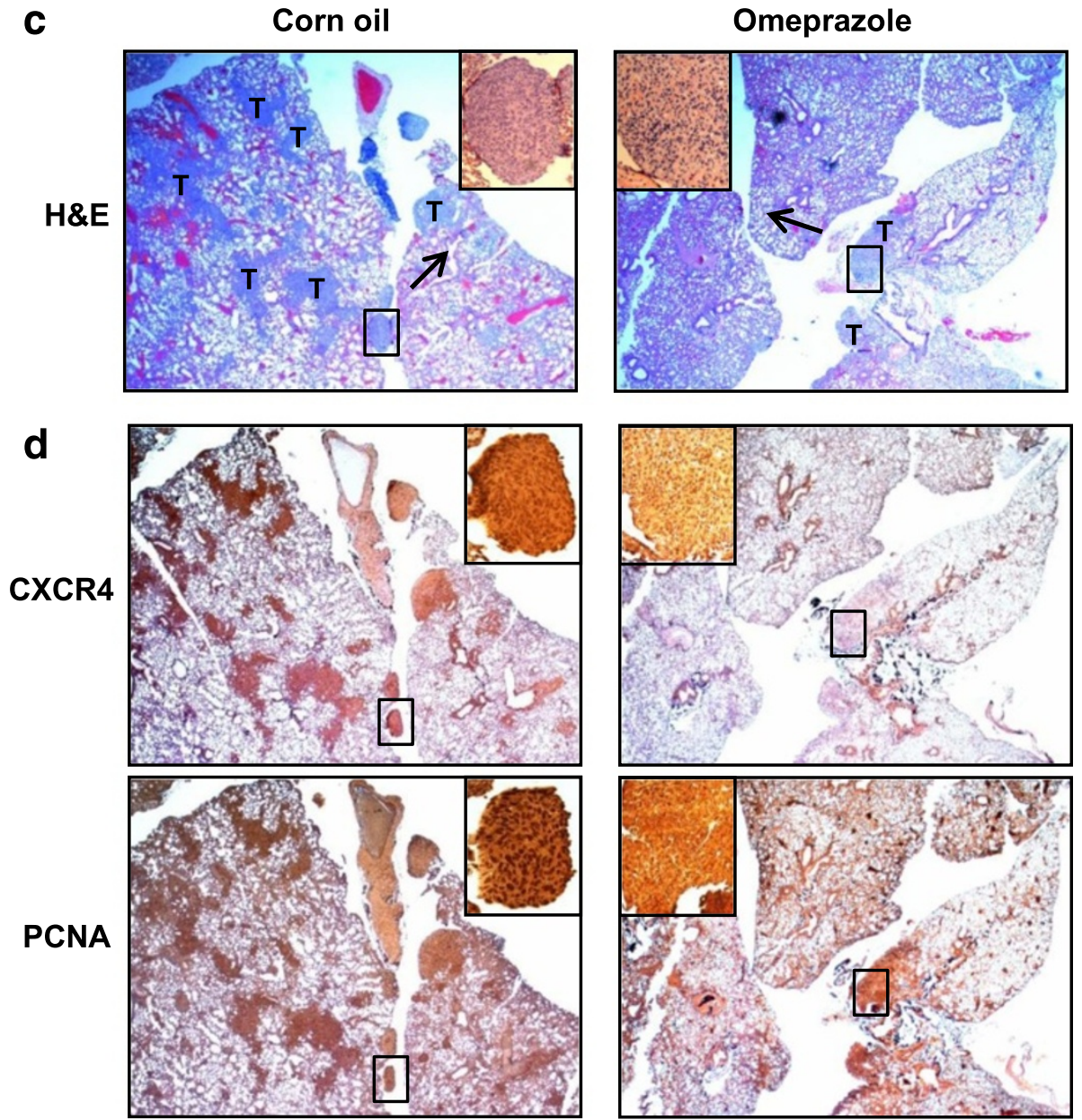

Figure $\mathbf{3}$ (See legend on next page.) 
(See figure on previous page.)

Figure 3 Omeprazole inhibits migration and invasion in vitro and metastasis in vivo. (a) Migration. MDA-MB-231 cells were treated with DMSO, TCDD or omeprazole, and cell migration was determined using a scratch assay as outlined in the Methods. (b) Decreased MMP-9 and CXCR4 expression. MDA-MB-231 cells were treated with DMSO, TCDD or omeprazole, and MMP-9 and CXCR4 mRNA levels were determined by real time PCR as outlined in the Methods. Results are means \pm SE for at least 3 replicate determinations and significant ( $p<0.05)$ inhibition is indicated. H\&E staining (c) and immunostaining (d) of lung tissue from in vivo studies. Lung tissue sections from animals treated with corn oil (control) or omeprazole $(100 \mathrm{mg} / \mathrm{kg} / \mathrm{d})$ were obtained for H\&E and immunostaining as outlined in the Methods. Image magnification 40x; inset magnification $100 \times$.

region of the promoter were used for determining recruitment or loss of AHR binding in a ChIP assay. Omeprazole (100-300 $\mu \mathrm{M})$ clearly induced AHR binding to DRE-123 and DRE-4 and, in the untreated cells, binding of this receptor was not observed at either DRE site (Figure 6B). The comparative effects of $10 \mathrm{nM}$ TCDD and $200 \mu \mathrm{M}$ omeprazole on inducing AHR binding to DRE-123 and DRE-4 in the CXCR4 promoter and the CYP1A1 DRE was also investigated in MDA-MB-231 cells, and both ligands induced AHR binding at all 3 cisDRE motifs (Figure 6C). In contrast, omeprazole and TCDD decreased binding of pol II to the CXCR4 promoter but increased pol II binding to the CYP1A1 gene promoter and this corresponded to the ligand-mediated suppression and induction of these genes, respectively. Recruitment of the corepressor SMRT to the CXCR4 promoter was not observed (data not shown), and the role of other nuclear cofactors in mediating AHRdependent downregulation of CXCR4 by TCDD and omeprazole is currently being investigated.

\section{Discussion}

The treatment and prognosis for breast cancer patients depends on multiple tumor characteristics including the size, stage, extent of tumor delocalization, and expression of various protein and mRNA prognostic factors [35]. Patients that express ER $\alpha$ can be successfully treated with antiestrogens and aromatase inhibitors, and more aggressive tumors that overexpress the epidermal growth factor receptor 2 (ErbB2) oncogene can be treated with the ErbB2 neutralizing antibody in combination therapies [36]. Patients with ER-negative tumors are among the most difficult to treat and exhibit low survival rates due, in part, to metastasis from the breast to various distal sites.

Research in this laboratory and others [33,34] have demonstrated that the AHR is a potential drug target for treating ER-negative breast cancer. For example, the SAhRM MCDF acts as an AhR agonist to inhibit growth and/or metastasis of ER-negative breast tumors in animal models, and this was associated with induction of microRNA-335 and the subsequent suppression of the pro-metastatic SOX4 gene [26]. Several other studies with structurally diverse AHR ligands (agonists) demonstrated AHR-mediated inhibition of cell migration and/ or invasion in ER-negative breast cancer cells and these responses were also accompanied by enhanced differentiation and downregulation of pro-metastatic genes such as CXCR4 and MMP-9 [31-34,37-39].

A number of pharmaceutical agents approved for multiple uses are also AHR ligands, and some of these compounds including 4-hydroxytamoxifen and tranilast exhibit some anticancer activity in breast cancer cells [37-39]. Our initial studies investigated the AHR agonist activities of eight AHR-active pharmaceuticals including tranilast and 4-hydroxytamoxifen in MDAMB-468 and BT474 breast cancer cells and observed that their AHR activity was structure-, cell contextand response-specific [27]. This variability in activity is illustrated by results for mexiletine which was an AHR antagonist in MDA-MB-468 cells and inhibited TCDDinduced CYP1A1 gene expression but was a partial AHR agonist in BT474 cells [27]. Moreover, in ER-negative MDA-MB-468 cells, several of the AHR pharmaceuticals including flutamide, leflunomide, nimodipine, omeprazole, sulindac and tranilast inhibited cell migration [27]. In this study, we primarily focused on the effects of the AHRactive pharmaceuticals in the more aggressive MDA-MB231 cell line which exhibits high basal rates of migration and also invasion in in vitro assays. However, we also observed that omeprazole induced CYP1A1 in MCF-7 and MDA-MB-468 cells (Figure 4A) [27]. The effects of the AHR-active pharmaceuticals on CYP1A1 and CYP1B1 expression in MDA-MB-231 cells were similar (Table 1); however, only omeprazole inhibited MDA-MB-231 cell invasion (Figures $1 \mathrm{D}$ and $2 \mathrm{~A}$ ) and we therefore selected this widely used proton pump inhibitor for further evaluation as an AHR-active antimetastatic agent in breast cancer. Previous studies suggest that omeprazole exhibits anti-inflammatory activity [40] and anticancer activity, particularly in combination treatment studies [41-43]. Since this investigation focused primarily on the effects of omeprazole alone, higher concentrations that were not cytotoxic were used in the cell culture experiments. Previous in vivo studies used an omeprazole dose of $75 \mathrm{mg} / \mathrm{kg}$ for administration of drug combinations and this dose had no effect on tumor growth [41]. A $100 \mathrm{mg} / \mathrm{kg}$ (daily) dose was used for investigating the in vivo antimetastic activity of omeprazole (Figure 3C,D). 
a

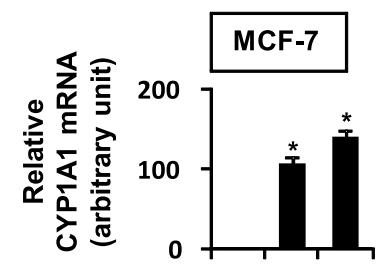

Omeprazole $(\mu \mathrm{M}) \quad 0100200$

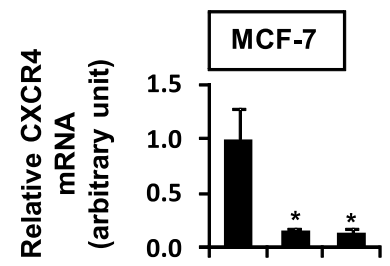

Omeprazole ( $\mu \mathrm{M}) \quad 0 \quad 100200$

b
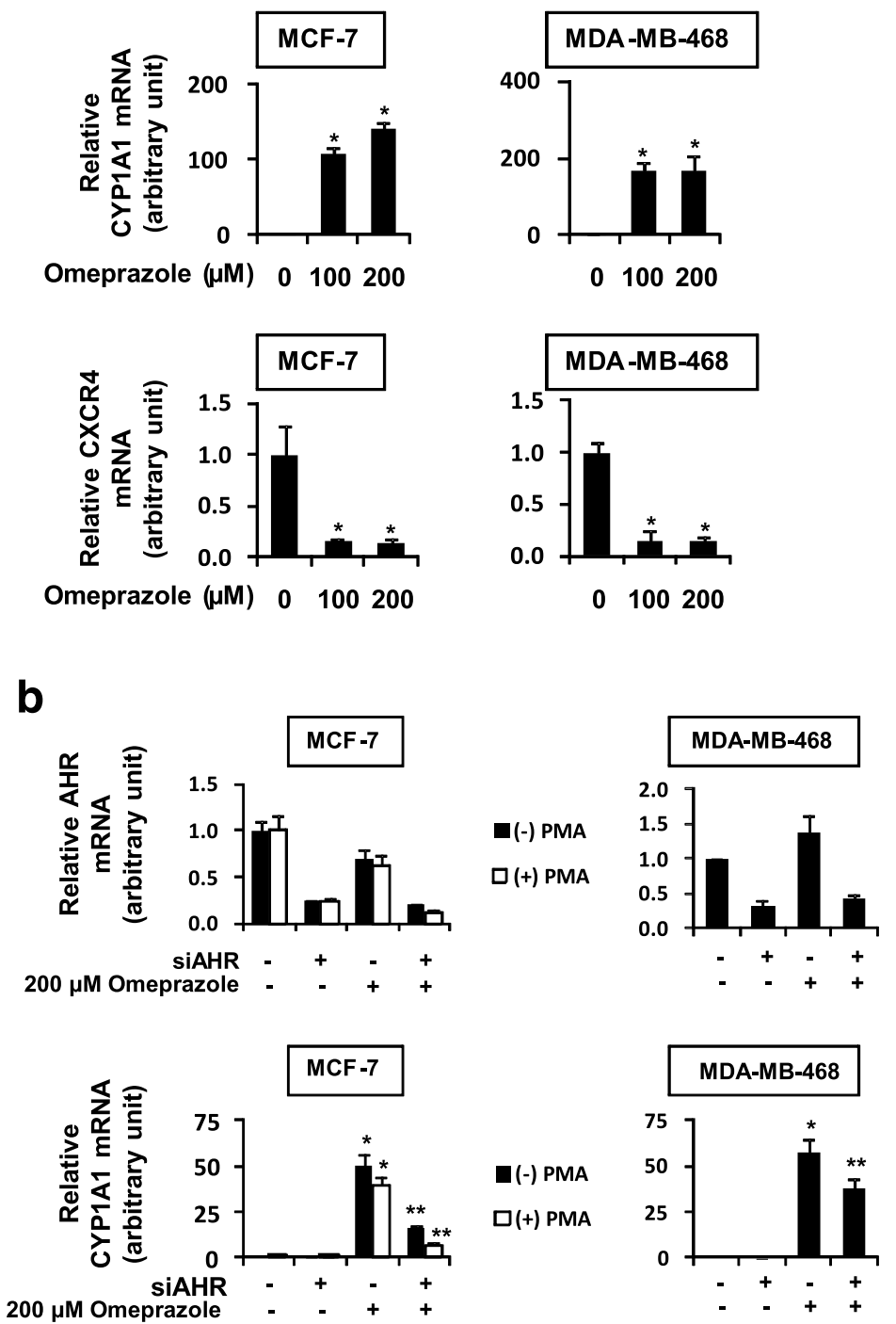

C
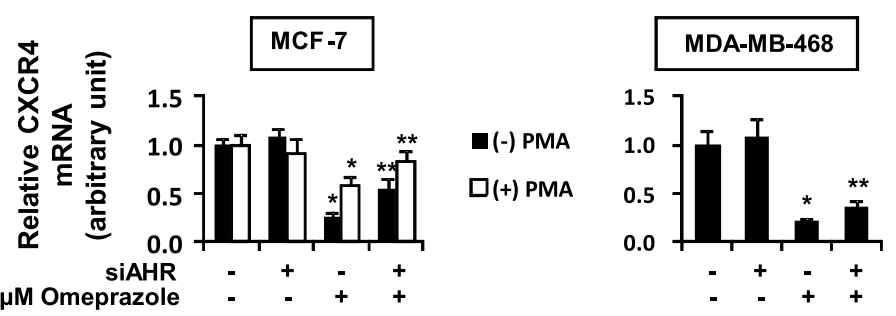

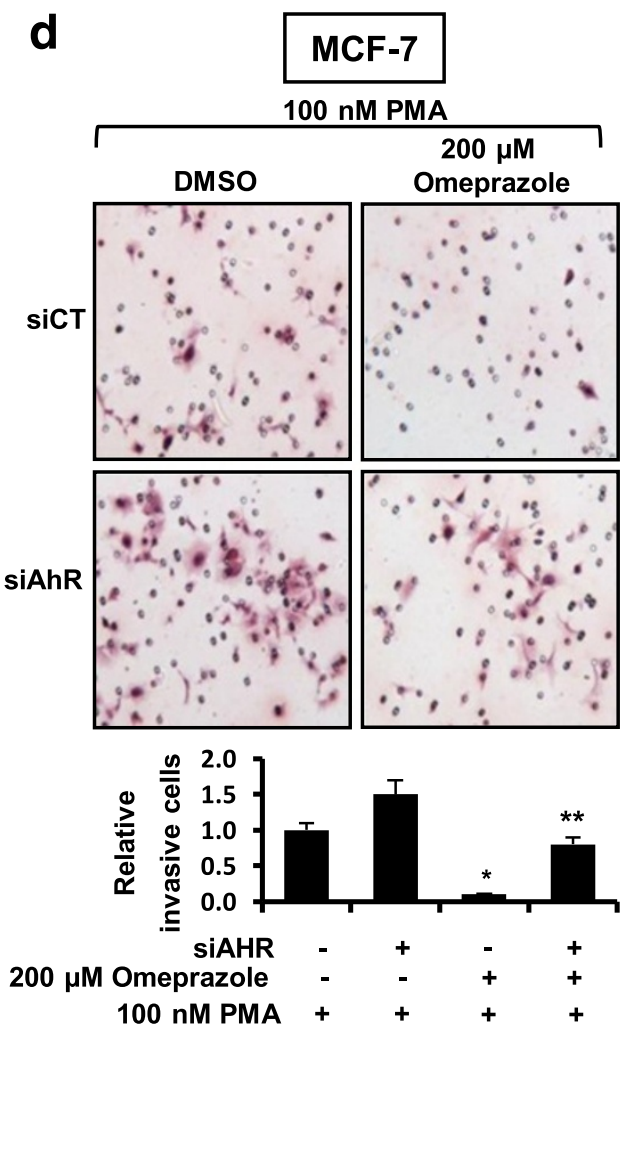

Figure 4 Role of omeprazole and the AHR in downregulation of CXCR4 and inhibition of invasion in MCF-7 and MDA-MB-468 cells. (a) CYP1A1 and CXCR4 mRNA. Cells were treated with 100 or $200 \mu \mathrm{M}$ omeprazole for $24 \mathrm{hr}$, and CXCR4 and CYP1A1 mRNA levels were determined as outlined in the Methods. (b) and (c) Role of the AHR. Cells were transfected with siAHR and treated with $200 \mu \mathrm{M}$ omeprazole, and expression of AHR and CYP1A1 (b) and CXCR4 (c) mRNA levels were determined as outlined in the Methods. MCF-7 cells were also cotreated with 100 nM PMA. (d) Effects of omeprazole on invasion of MCF-7 cells. Cells were transfected with siCtl (non-specific) or siAHR and treated with DMSO or $200 \mu \mathrm{M}$ omeprazole plus PMA (MCF-7 cells), and cell invasion was determined in a Boyden chamber assay as outlined in the Methods. Results (a-d) are means \pm SE for at least 3 replicate determinations for each data point. Significantly $(p<0.05)$ increased CYP1A1 or decreased CXCR4 $\left({ }^{*}\right)$ and reversal of these effects by siAHR $\left.{ }^{* *}\right)$ are indicated. AHR mRNA was significantly $(p<0.05)$ decreased by siAHR in all 3 cell lines. 
a

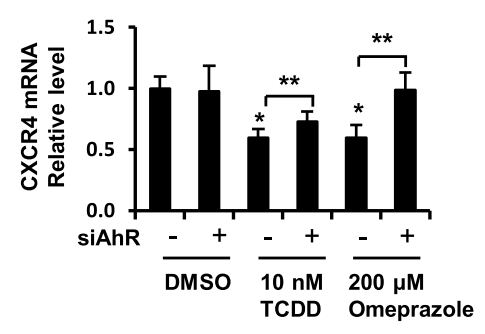

b

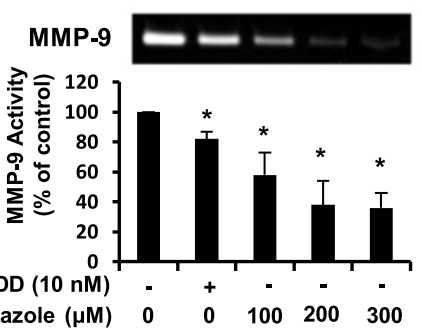

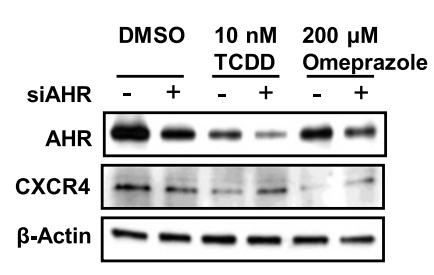

DMSO Omeprazole

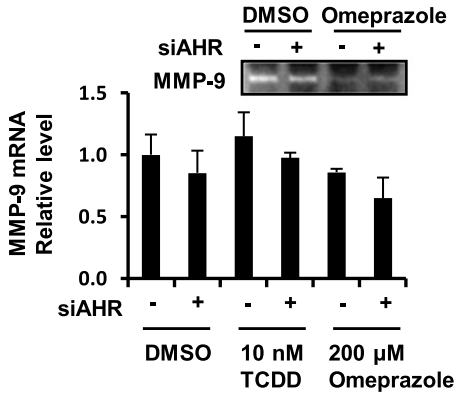

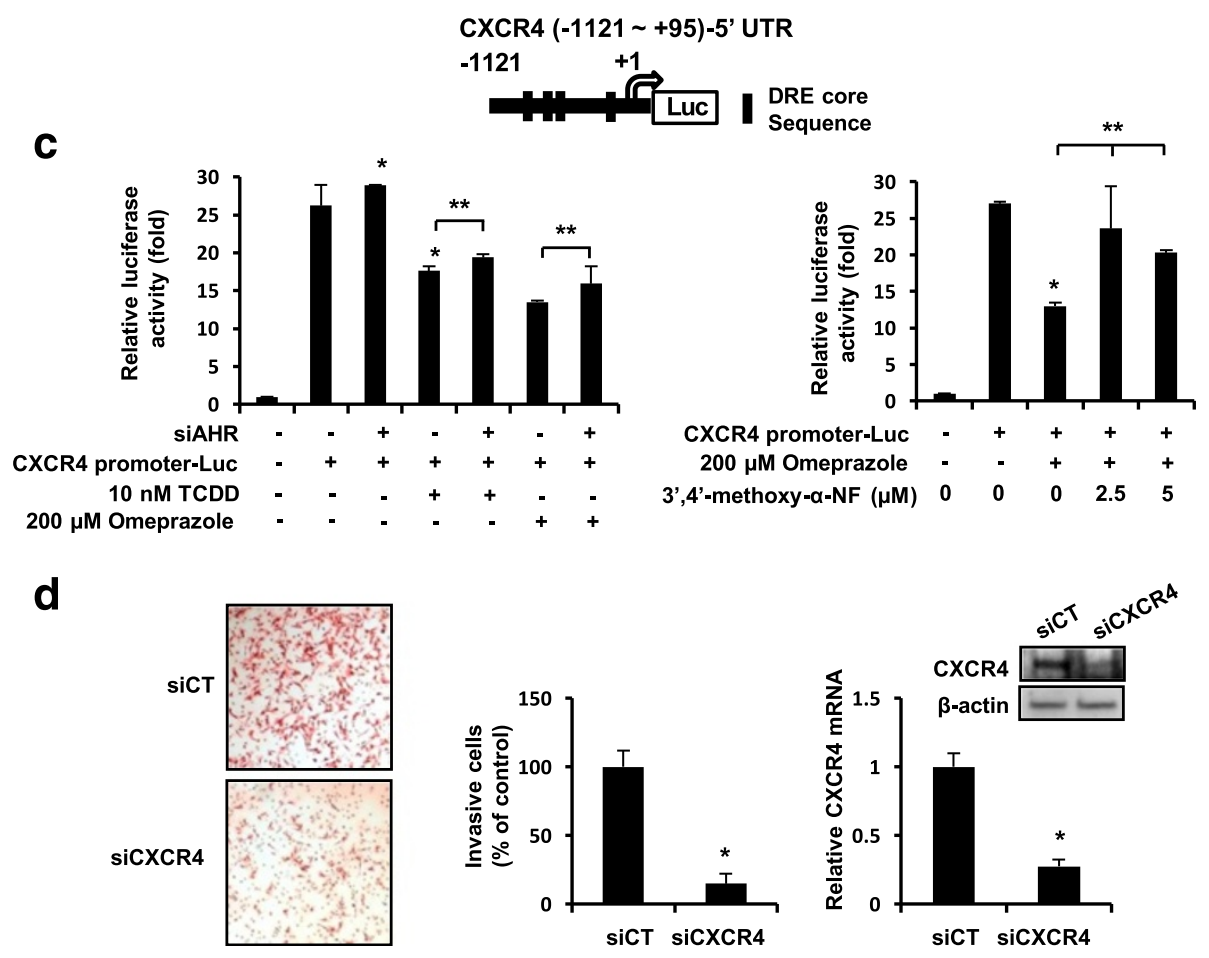

Figure 5 Omeprazole and TCDD decrease CXCR4 and MMP-9. (a) CXCR4 mRNA and protein. MDA-MB-231 cells were treated with DMSO, omeprazole or TCDD and transfected with siCtl (control) or si AHR, and mRNA and protein levels were determined as described in the Methods. (b) Effects on MMP-9. Cells were treated with DMSO, TCDD or omeprazole, and MMP-9 activity (zymography) and MMP-9 mRNA levels (in cells transfected with siCtl or siAHR) were determined as outlined in the Methods. (c) CXCR4 promoter activity. MDA-MB-231 cells were transfected with CXCR4-(-1121 to +95)luc and either cotransfected with siCtl and siAHR or treated with 3',4'-dimethoxy-a-naphthoflavone and luciferase activity determined as outlined in the Methods. (d) Silencing of CXCR4. Cells were transfected with siCtl or siCXCR4 and effects on cancer cell invasion and CXCR4 expression were determined as outlined in the Methods. Results (a-d) are means \pm SE for at least 3 experiments and significant $(p<0.05)$ decrease $(*)$ or rescue $\left(^{* *}\right)$ is indicated. 


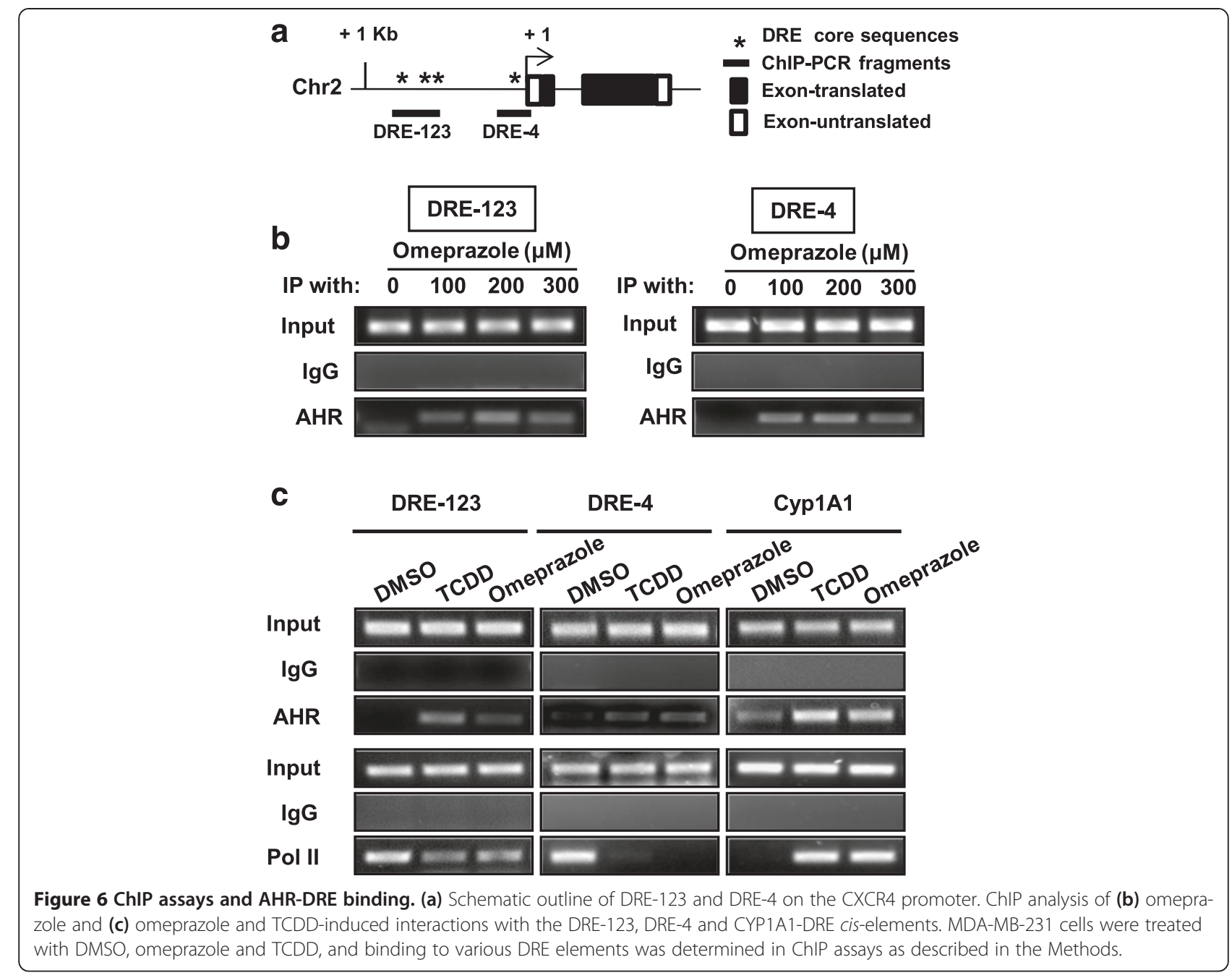

Omeprazole clearly inhibited MDA-MB-231 cell migration and invasion (Figures $2 \mathrm{~A}$ and $3 \mathrm{~A}$ ) and this response was attenuated after knockdown of the AHR by RNAi or after cotreatment with AHR antagonists (Figure 2A-C). MDA-MB-468 cells did not exhibit invasion; however, omeprazole inhibited PMA-induced invasion of MCF-7 cells and this response was also attenuated after AHR knockdown (Figure 4D). Moreover, these in vitro assays were complemented by inhibition of lung metastasis of MDA-MB-231 cells in mice administered the cells by tail vein injection and treated with omeprazole (Figure 3B). In contrast to the effects observed for MCDF [26], omeprazole did not induce miR-335 expression in MDA-MB-231 (data not shown), but significantly decreased expression of the pro-metastatic genes MMP-9 and CXCR4 (Figure 5A,B) and similar results were observed in MCF-7 and MDA-MB-468 cells (Figure 4C). Previous studies show that one or both of these genes was decreased in ER-positive cells and tumors treated with structurally diverse AHR ligands [31-34]. We also observed that CXCR4 (and PCNA) expression was also decreased in metastasized tumors (lung) (Figure 3D), suggesting that omeprazole not only decreased metastasis but directly targeted CXCR4 and PCNA in the metastasized tumors. We further investigated the role of the AHR in mediating the induction of MMP-9 and CXCR4 by omeprazole in MDA-MB-231 cells and our results show that although AHR silencing may decrease MMP-9 activity (zymography), the loss of the receptor does not attenuate the effects of omeprazole on MMP-9 (Figure 4B). In contrast, omeprazole-induced downregulation of CXCR4 was significantly reversed by AHR silencing or cotreatment with AHR antagonists (Figure $5 \mathrm{~A}, \mathrm{C}$ ), suggesting that downregulation of MMP-9 and CXCR4 by omeprazole in MDA-MB-231 cells is AHR-independent and -dependent, respectively.

Although the AHR and other nuclear receptors mediate induction and expression of genes, most mechanistic studies have focused on activation of genes and the ligand-dependent recruitment of the AHR and nuclear 
cofactors to DREs in Ah-responsive gene promoters [44]. Treatment of MDA-MB-231 cells with omeprazole or TCDD resulted in recruitment of the AHR to the CYP1A1 gene promoter and this was accompanied recruitment of pol II (Figure 6C) and induction of CYP1A1 gene expression (Additional file 1: Figure S1 and Additional file 1: Figure S3). The CXCR4 promoter contains two regions with cis-elements consistent with DRE sequences (DRE123 and DRE-4). Omeprazole decreased luciferase activity in MDA-MB-231 cells transfected with the pGL3-CXCR4 $(-1121$ to +95$)$ construct which contains these DREs and this response was attenuated by AHR silencing or AHR antagonists (Figure 4C). Omeprazole and TCDD also induced AHR binding to the CXCR4 promoter (Figure 6B,C); however, in contrast to the recruitment of pol II to the CYP1A1 promoter, both TCDD and omeprazole decreased pol II interactions with the CXCR4 promoter (Figure 6C) and this was consistent with omeprazole-mediated repression of CXCR4 gene expression. We did not observe ligand-dependent recruitment of the corepressor SMRT to the CXCR4 promoter and are currently investigating the role of other nuclear cofactors required for AHR-mediated suppression of CXCR4 and other genes in cancer cells treated with omeprazole. Thus, the anticancer activity of omeprazole is due, in part, to the AhR but this does not exclude a role for other AhR-independent pathways.

\section{Conclusions}

In summary, results of this study demonstrate that among several AHR-active pharmaceuticals, omeprazole exhibits antimetastatic activity for triple-negative MDAMB-231 breast cancer cells, and CXCR4 is one of the key target genes not only for omeprazole but also for other AHR agonists [31-34]. AHR-dependent downregulation of CXCR4 by omeprazole significantly contributed to the antimetastatic activity of this compound since silencing of CXCR4 by RNAi in MDA-MB-231 cells also inhibited invasion of these cells in a Boyden chamber assay (Figure 5D). Since CXCR4 has both functional and prognostic significance for metastasis in breast tumors and cells [45], the antimetastatic activity of omeprazole and other AHR-active pharmaceuticals including other benzimidazole protein pump inhibitors are currently being investigated. The anticancer activity of drugs used for treatment of gastroesophageal reflux disease is not well established [46] and it is possible that chemotherapeutic effects of omeprazole for inhibition of breast cancer metastasis may require higher doses than are typically used for treating acid reflux. However, lower doses of omeprazole may be effective for drug combination therapies [41] and these are currently being investigated.

\section{Additional files}

Additional file 1: Figure S1. Induction of CYP1A1 mRNA by AHR-active pharmaceuticals. MDA-MB-231 cells were treated with DMSO, different concentrations of pharmaceuticals and $10 \mathrm{nM}$ TCDD, and CYP1A1 mRNA levels were determined by real time PCR as outlined in the Methods. Results are expressed as means \pm SE for 3 replicate determinations.

Additional file 2: Figure S2. Induction of CYP1B1 mRNA by AHR-active pharmaceuticals. MDA-MB-231 cells were treated with DMSO, different concentrations of pharmaceuticals and $10 \mathrm{nM}$ TCDD, and CYP1B1 mRNA levels were determined by real time PCR as outlined in the Methods. Results are expressed as means \pm SE for 3 replicate determinations.

Additional file 3: Figure S3. Effects of AHR-active pharmaceuticals and TCDD on CYP1A1 and AHR proteins. MDA-MB-231 cells were treated with DMSO, TCDD and AHR-active pharmaceuticals for $24 \mathrm{hr}$, and whole cell lysates were analyzed by western blots as outlined in the Methods.

Additional file 4: Figure S4. Growth inhibition. MDA-MB-231 cells were treated with DMSO, different concentrations of AHR-active pharmaceuticals for $24 \mathrm{hr}$, and cell growth was determined using MTT assay as outlined in the Methods. Results are expressed as means \pm SE for at least 3 replicate determinations.

\section{Abbreviations}

6-MCDF: 6-methyl-1,3,8-trichlorodibenzofuran; AHR: Aryl hydrocarbon receptor; AhREs: Aryl hydrocarbon response elements; ARNT: Aryl hydrocarbon receptor nuclear translocator; ChIP: Chromatin immunoprecipitation; DMEM: Dulbecco's modified Eagle's medium; DMSO: Dimethyl sulfoxide; DREs: Dioxin response elements; ER: Estrogen receptor; FBS: Fetal bovine serum; miR-335: MicroRNA-335; RNAi: RNA interference; SAhRMs: Selective aryl hydrocarbon receptor modulators; TCDD: 2,3,7,8-tetrachlorodibenzo-p-dioxin.

\section{Competing interest}

The authors declare that have no competing interest.

\section{Authors' contributions}

$\mathrm{UHJ}$ carried out most of the in vivo and in vitro studies. SOL assisted UHJ in the in vivo studies and the immunostaining experiments. CP carried out the pathology studies. SS supervised the project and wrote the paper. All authors read and approved the final manuscript.

\section{Acknowledgements}

The financial assistance from National Institutes of Health (R01-CA142697) and Texas AgriLife Research is gratefully appreciated.

\section{Author details}

${ }^{1}$ Institute of Biosciences and Technology, Texas A\&M Health Sciences Center, 2121 W. Holcombe Blvd., Houston, TX 77030, USA. ²Department of Veterinary Pathobiology, Texas A\&M University, 4466 TAMU, College Station, TX 77843, USA. ${ }^{3}$ Department of Veterinary Physiology and Pharmacology, Texas A\&M University, 4466 TAMU, College Station, TX 77843, USA.

Received: 25 October 2013 Accepted: 2 July 2014

Published: 9 July 2014

\section{References}

1. Poland A, Glover E, Kende AS: Stereospecific, high affinity binding of 2,3,7,8-tetrachlorodibenzo-p-dioxin by hepatic cytosol: evidence that the binding species is receptor for induction of aryl hydrocarbon hydroxylase. J Biol Chem 1976, 251:4936-4946.

2. Hoffman EC, Reyes H, Chu FF, Sander F, Conley LH, Brooks BA, Hankinson O: Cloning of a factor required for activity of the Ah (dioxin) receptor. Science 1991, 252:954-958.

3. Denison MS, Soshilov AA, He G, DeGroot DE, Zhao B: Exactly the same but different: promiscuity and diversity in the molecular mechanisms of action of the aryl hydrocarbon (dioxin) receptor. Toxicol Sci 2011, 124:1-22. 
4. Safe SH: Comparative toxicology and mechanism of action of polychlorinated dibenzo-p-dioxins and dibenzofurans. Annu Rev Pharmacol Toxicol 1986, 26:371-399.

5. Denison MS, Nagy SR: Activation of the aryl hydrocarbon receptor by structurally diverse exogenous and endogenous chemicals. Annu Rev Pharmacol Toxicol 2003, 43:309-334.

6. Safe SH, Chadalapaka G, Jutooru I: AHR-Active Compounds in the Human Diet. In The AH Receptor in Biology and Toxicology. edn. Edited by Pohjanvirta R. Hoboken, NJ: Wiley; 2012:331-342.

7. Denison MS, Seidel SD, Rogers WJ, Ziccardi M, Winter GM, Heath-Pagliuso S: Natural and Synthetic Ligands for the Ah Receptor. In Molecular Biology Approaches to Toxicology. edn. Edited by Puga A, Wallace KB. Philadelphia, PA: Taylor \& Francis; 1998:393-410.

8. DiNatale BC, Schroeder JC, Francey LJ, Kusnadi A, Perdew GH: Mechanistic insights into the events that lead to synergistic induction of interleukin 6 transcription upon activation of the aryl hydrocarbon receptor and inflammatory signaling. J Biol Chem 2010, 285:24388-24397.

9. Murray IA, Krishnegowda G, DiNatale BC, Flaveny C, Chiaro C, Lin JM, Sharma AK, Amin S, Perdew GH: Development of a selective modulator of aryl hydrocarbon (Ah) receptor activity that exhibits anti-inflammatory properties. Chem Res Toxicol 2010, 23:955-966.

10. Benson JM, Shepherd DM: Aryl hydrocarbon receptor activation by TCDD reduces inflammation associated with Crohn's disease. Toxicol Sci 2011, 120:68-78.

11. Murray IA, Morales JL, Flaveny CA, Dinatale BC, Chiaro C, Gowdahalli K Amin S, Perdew GH: Evidence for ligand-mediated selective modulation of aryl hydrocarbon receptor activity. Mol Pharmacol 2010, 77:247-254

12. Boitano AE, Wang J, Romeo R, Bouchez LC, Parker AE, Sutton SE, Walker JR, Flaveny CA, Perdew GH, Denison MS, Schultz PG, Cooke MP: Aryl hydrocarbon receptor antagonists promote the expansion of human hematopoietic stem cells. Science 2010, 329:1345-1348.

13. Quintana FJ, Basso AS, Iglesias AH, Korn T, Farez MF, Bettelli E, Caccamo M, Oukka M, Weiner HL: Control of $\mathrm{T}(\mathrm{reg})$ and $\mathrm{T}(\mathrm{H}) 17$ cell differentiation by the aryl hydrocarbon receptor. Nature 2008, 453:65-71.

14. Veldhoen M, Hirota K, Westendorf AM, Buer J, Dumoutier L, Renauld JC, Stockinger B: The aryl hydrocarbon receptor links TH17-cell-mediated autoimmunity to environmental toxins. Nature 2008, 453:106-109.

15. Kerkvliet NI, Steppan LB, Vorachek W, Oda S, Farrer D, Wong CP, Pham D, Mourich DV: Activation of aryl hydrocarbon receptor by TCDD prevents diabetes in NOD mice and increases Foxp3+ T cells in pancreatic lymph nodes. Immunotherapy 2009, 1:539-547.

16. Safe S, Qin C, McDougal A: Development of selective aryl hydrocarbon receptor modulators for treatment of breast cancer. Expert Opin Investig Drugs 1999, 8:1385-1396.

17. McDougal A, Wormke M, Calvin J, Safe S: Tamoxifen-induced antitumorigenic/antiestrogenic action synergized by a selective aryl hydrocarbon receptor modulator. Cancer Res 2001, 61:3902-3907.

18. Astroff B, Zacharewski T, Safe S, Arlotto MP, Parkinson A, Thomas P, Levin W: 6-Methyl-1,3,8-trichlorodibenzofuran as a 2,3,7,8-tetrachlorodibenzo-p-dioxin antagonist: inhibition of the induction of rat cytochrome P-450 isozymes and related monooxygenase activities. Mol Pharmacol 1988, 33:231-236

19. Harris M, Zacharewski T, Astroff $B$, Safe S: Partial antagonism of 2,3,7,8-tetrachlorodibenzo-p-dioxin-mediated induction of aryl hydrocarbon hydroxylase by 6-methyl-1,3,8-trichlorodibenzofuran: mechanistic studies. Mol Pharmacol 1989, 35:729-735.

20. Bannister R, Biegel L, Davis D, Astroff B, Safe S: 6-Methyl-1,3,8-trichlorodibenzofuran (MCDF) as a 2,3,7,8- tetrachlorodibenzo-p-dioxin antagonist in C57BL/6 mice. Toxicology 1989, 54:139-150.

21. Yao C, Safe $S:$ 2,3,7,8-Tetrachlorodibenzo-p-dioxin-induced porphyria in genetically inbred mice: partial antagonism and mechanistic studies. Toxicol Appl Pharmacol 1989, 100:208-216

22. Astroff B, Safe S: 6-Substituted-1,3,8-trichlorodibenzofurans as 2,3,7,8-tetrachlorodibenzo-p-dioxin antagonists in the rat: structure activity relationships. Toxicology 1989, 59:285-296.

23. Astroff B, Safe S: 6-Alkyl-1,3,8-trichlorodibenzofurans as antiestrogens in female Sprague-Dawley rats. Toxicology 1991, 69:187-197.

24. Zacharewski T, Harris M, Biegel L, Morrison V, Merchant M, Safe S: 6-Methyl-1,3,8-trichlorodibenzofuran (MCDF) as an antiestrogen in human and rodent cancer cell lines: evidence for the role of the Ah receptor. Toxicol Appl Pharmacol 1992, 113:311-318.
25. Zhang S, Lei P, Liu X, Li X, Walker K, Kotha L, Rowlands C, Safe S: The aryl hydrocarbon receptor as a target for estrogen receptor-negative breast cancer chemotherapy. Endocr Relat Cancer 2009, 16:835-844.

26. Zhang S, Kim K, Jin UH, Pfent C, Cao H, Amendt B, Liu X, Wilson-Robles H, Safe S: Aryl hydrocarbon receptor agonists induce microRNA-335 expression and inhibit lung metastasis of estrogen receptor negative breast cancer cells. Mol Cancer Ther 2012, 11:108-118.

27. Jin UH, Lee SO, Safe S: Aryl hydrocarbon receptor (AHR)-active pharmaceuticals are selective AHR modulators in MDA-MB-468 and BT474 breast cancer cells. J Pharmacol Exp Ther 2012, 343:333-341.

28. Wittmann BM, Sherk A, McDonnell DP: Definition of functionally important mechanistic differences among selective estrogen receptor down-regulators. Cancer Res 2007, 67:9549-9560.

29. Murray IA, Flaveny CA, Chiaro CR, Sharma AK, Tanos RS, Schroeder JC, Amin SG, Bisson WH, Kolluri SK, Perdew GH: Suppression of cytokine-mediated complement factor gene expression through selective activation of the Ah receptor with 3',4'-dimethoxy-alpha-naphthoflavone. Mol Pharmacol 2011, 79:508-519.

30. Lu YF, Santostefano M, Cunningham BD, Threadgill MD, Safe S: Identification of 3'-methoxy-4'-nitroflavone as a pure aryl hydrocarbon (Ah) receptor antagonist and evidence for more than one form of the nuclear Ah receptor in MCF-7 human breast cancer cells. Arch Biochem Biophys 1995, 316:470-477.

31. Hsu EL, Yoon D, Choi HH, Wang F, Taylor RT, Chen N, Zhang R, Hankinson O: A proposed mechanism for the protective effect of dioxin against breast cancer. Toxicol Sci 2007, 98:436-444.

32. Hsu EL, Chen N, Westbrook A, Wang F, Zhang R, Taylor RT, Hankinson O: CXCR4 and CXCL12 down-regulation: a novel mechanism for the chemoprotection of 3,3'-diindolylmethane for breast and ovarian cancers. Cancer Lett 2008, 265:113-123.

33. Hall JM, Barhoover MA, Kazmin D, McDonnell DP, Greenlee WF, Thomas RS: Activation of the aryl-hydrocarbon receptor inhibits invasive and metastatic features of human breast cancer cells and promotes breast cancer cell differentiation. Mol Endocrinol 2010, 24:359-369.

34. Wang T, Gavin HM, Arlt VM, Lawrence BP, Fenton SE, Medina D, Vorderstrasse BA: Aryl hydrocarbon receptor activation during pregnancy, and in adult nulliparous mice, delays the subsequent development of DMBA-induced mammary tumors. Int J Cancer 2011, 128:1509-1523.

35. Moulder S, Hortobagyi GN: Advances in the treatment of breast cancer. Clin Pharmacol Ther 2008, 83:26-36.

36. Demonty G, Bernard-Marty C, Puglisi F, Mancini I, Piccart M: Progress and new standards of care in the management of HER-2 positive breast cancer. Eur J Cancer 2007, 43:497-509.

37. DuSell CD, Nelson ER, Wittmann BM, Fretz JA, Kazmin D, Thomas RS, Pike JW, McDonnell DP: Regulation of aryl hydrocarbon receptor function by selective estrogen receptor modulators. Mol Endocrinol 2010, 24:33-46

38. Subramaniam $\vee$, Ace $O$, Prud'homme GJ, Jothy S: Tranilast treatment decreases cell growth, migration and inhibits colony formation of human breast cancer cells. Exp Mol Pathol 2011, 90:116-122.

39. Subramaniam V, Chakrabarti R, Prud'homme GJ, Jothy S: Tranilast inhibits cell proliferation and migration and promotes apoptosis in murine breast cancer. Anticancer Drugs 2010, 21:351-361.

40. Kedika RR, Souza RF, Spechler SJ: Potential anti-inflammatory effects of proton pump inhibitors: a review and discussion of the clinical implications. Dig Dis Sci 2009, 54:2312-2317.

41. Luciani F, Spada M, De Milito A, Molinari A, Rivoltini L, Montinaro A, Marra M, Lugini L, Logozzi M, Lozupone F, Federici C, lessi E, Parmiani G, Arancia G, Belardelli F, Fais S: Effect of proton pump inhibitor pretreatment on resistance of solid tumors to cytotoxic drugs. J Nat/ Cancer Inst 2004, 96:1702-1713.

42. Ishiguro $T$, Ishiguro M, Ishiguro R, Iwai S: Cotreatment with dichloroacetate and omeprazole exhibits a synergistic antiproliferative effect on malignant tumors. Oncol Lett 2012, 3:726-728.

43. Udelnow A, Kreyes A, Ellinger $\mathrm{S}$, Landfester $\mathrm{K}$, Walther $\mathrm{P}$, Klapperstueck T, Wohlrab J, Henne-Bruns D, Knippschild U, Wurl P: Omeprazole inhibits proliferation and modulates autophagy in pancreatic cancer cells. PLOS ONE 2011, 6:e20143.

44. Matthews J, Wihlen B, Thomsen J, Gustafsson JA: Aryl hydrocarbon receptor-mediated transcription: ligand-dependent recruitment of 
estrogen receptor alpha to 2,3,7,8-tetrachlorodibenzo-p-dioxin-responsive promoters. Mol Cell Biol 2005, 25:5317-5328.

45. Cabioglu N, Yazici MS, Arun B, Broglio KR, Hortobagyi GN, Price JE, Sahin A: CCR7 and CXCR4 as novel biomarkers predicting axillary lymph node metastasis in T1 breast cancer. Clin Cancer Res 2005, 11:5686-5693.

46. Miyashita T, Shah FA, Harmon JW, Marti GP, Matsui D, Okamoto K, Makino I, Hayashi H, Oyama K, Nakagawara H, Tajima H, Fujita H, Takamura H, Murakami M, Ninomiya I, Kitagawa H, Fushida S, Fujimura T, Ohta T: Do proton pump inhibitors protect against cancer progression in GERD? Surg Today 2013, 43:831-837.

doi:10.1186/1471-2407-14-498

Cite this article as: Jin et al.: The aryl hydrocarbon receptor ligand omeprazole inhibits breast cancer cell invasion and metastasis. BMC Cancer 2014 14:498.

\section{Submit your next manuscript to BioMed Central and take full advantage of:}

- Convenient online submission

- Thorough peer review

- No space constraints or color figure charges

- Immediate publication on acceptance

- Inclusion in PubMed, CAS, Scopus and Google Scholar

- Research which is freely available for redistribution 